\title{
Living in the New Regional Context: Rethinking an ASEAN Economic Community
}

\author{
Chulanee Tantikulananta \\ College of Interdisciplinary Studies, Thammasat University, Bangkok, Thailand
}

\begin{abstract}
Since the 1997 Asian financial crisis, ASEAN has been faced with new challenges and there has been fierce economic competition, particularly from China, as its economic influence has continued to grow. To reinforce its regional attraction for FDI and investors, ASEAN agreed to establish the ASEAN Economic Community (AEC) by the end of 2015. The formation of the AEC has spotlighted ASEAN as a role model for regional economic cooperation in developing countries. Significantly, the establishment of the AEC underscores ASEAN's intention to retain its notionally influential position at the center stage of the region. Though a number of tasks have been met, significant challenges also remain. Evidence reveals that slow progress on ASEAN integration is a result of the ineffectiveness of ASEAN institutions, and the fact that member states still prioritize the preservation of their national interests. Furthermore, the changes in the regional economic environment, particularly the increasing Chinese engagement in Asia and ASEAN, are affecting the formation of the AEC. Hence, the paper argues that the formation of the AEC is much shaped by the dynamic interplay of regional and extra regional influences. Thus, the paper will attempt to identify the key hurdles that hinder member states from achieving its end goal and also speculates on the future of ASEAN economic cooperation.
\end{abstract}

Keywords: AEC, ASEAN, China, New Regionalism, NTBs

\section{Introduction}

From its inception in 1967, the Association of Southeast Asian Nations (ASEAN) "has gained almost successful paradigmatic status for South-South cooperation" [1]. The apparent success of ASEAN in maintaining peaceful relations has contributed to its distinctive diplomatic style, the ASEAN Way, which emphasizes consultation, consensus and implicit sensitivity regarding the domestic circumstances of its members. Though ASEAN manifests diverse economic and political structures, ASEAN expanded its cooperation to outside the region in 1990s, due to the fear of investment being diverted to China. To continue its participation in the international trading system, ASEAN member states (AMS) implemented the ASEAN Free Trade Area (AFTA) [2] in 1992 and the agreement has attracted much attention from academic circles under the concept of new regionalism. Later, various economic schemes have been launched including the ASEAN Framework Agreement on Services (AFAS) [3] and the ASEAN Investment Area (AIA) [4].

Since the late 1990s, ASEAN has faced many constraints. When the 1997 Asian financial crisis hit the region, ASEAN proved powerless and was unable to react as a coordinated regional economic group [5]. At the national level, the crisis also exposed the fragility of many ASEAN economies and also highlighted the persistence of economic cronyism. At the regional level, it revealed the inadequacy of ASEAN institutional structures particularly the ASEAN way. Thus, Thailand Malaysia, and Indonesia faced serious problems, particularly negative economic growth, demand decline and stagnant FDI. Apart from the 1997 economic downturn, ASEAN also faced new challenges because of the rise of China. China's rapid economic growth and its accession to the World Trade Organization (WTO) have made it an increasingly important competitor with ASEAN countries in terms of trade and investment.

To improve their economic prospects and create a competitive economic region, ASEAN leaders agreed at the ASEAN Concord II in 2003 to establish the ASEAN Economic Community (AEC) by 2020 [6]. This deadline was later brought forward to January 1, 2015 [7]. However, at the $21^{\text {st }}$ ASEAN Summit, the commencement of the AEC was postponed to December 31, 2015 because a lot of work still remained to be done. Undoubtedly, observers are pessimistic about the inauguration of the AEC by the end of this year. On the one hand, as the AEC is built on the current initiatives under AFTA, AFAS and AIA, this should not obscure the fact that these economic schemes have had limited success due to the weaknesses of institutional structures, 
the expansion of its membership and non-tariff barriers (NTBs) [8] [9]. On the other hand, the increasing engagement of China in the region has dramatic economic implications for the AEC. This is because ASEAN economic cooperation remains weaving in its powerful Northeast Asian neighbours particularly China. Significantly, there is the shift from Pacific Rim organizations to Asian forms centered on ASEAN and China.

To understand the development and progress of the AEC, the central argument developed here is that analysis requires the consideration of both internal and external factors. Therefore, there are several issues that this paper tackles. First, it outlines the formation of the AEC, The paper moves further to identify the key hurdles preventing and affecting the formation of the AEC. In doing so, two significant factors are examined: obstacles within ASEAN and the increasing engagement of China in the region. These factors will provide an explanation for the progress, or lack thereof, of the AEC. Finally, the paper will speculate on the future of ASEAN economic cooperation under the AEC.

\section{ASEAN's New Life Under the AEC}

The shock of the 1997 crisis has damaged the image of ASEAN's dramatic economic growth as a flying geese and its regional credit as the driving force of the Asia Pacific region. Its inability to cope with the crisis was due to a lack of instruments for dealing with economic and political consequences [10] [11]. In the meantime, China's accession to the WTO and the rise of emerging markets, particularly the BRIC (Brazil, Russia, India, China and South Africa), forced ASEAN members to cooperate so that the region would continue to attract businesses and investors. To regain its credibility, and to secure its position as an economic leader, ASEAN leaders agreed at the ASEAN Concord II in 2003 to establish the ASEAN Economic Community (AEC) [12] by 2020. The timetable was later brought forward to 2015.

The AEC is based on four characteristics: Single Market and production base; Competitive economic region; Equitable economic development; and Integration into the Global Economy. The AEC is expected "to impress upon the international business sector and public at large that ASEAN was serious about integrating the regional economy into a form deeper than a free trade area" [13]. In the other words, the AEC is considered a defense mechanism for ASEAN against FDI loss and also as an extension of trade liberalization of its member states [14]. Thus the AEC is expected to allow the member states to benefit from economies of scale and efficiency in production network processes [15]. It is expected to increase intra-regional trade and investment due to the elimination of economic barriers.

In November 2007, ASEAN leaders approved a 'Roadmap' consisting of a Blueprint for the AEC. To monitor and ensure the timely implementation of the AEC initiatives, the AEC scorecard was established. The scorecard revealed that ASEAN has made considerable progress in implementing the AEC. ASEAN has performed best under the fourth pillar which concerns integration into the global economy (85.7\%); however, ASEAN received the lowest score of $66.5 \%$ for Pillar I (Single Market and Production Base). Apart from the scorecard, the achievement of ASEAN has been underscored by the mid-term review (MTR) on the investment liberalization commitment in the goods sector under the ATIGA which is remarkably liberal in most AMS [16].

\section{Challenges to Implementing the AEC}

In 2012, ASEAN leaders agreed to delay the launch of the AEC for 12 months until 31 December 2015. The former ASEAN Secretary-General Surin Pitsuwan reassured that "there will be no more delays and that all ten ASEAN countries will participate" [17]. Although the scorecard is a good reflection of ASEAN progress, a number of scholars have criticized the scorecard as some significant data have been neglected by it as well as by other ASEAN official reports and the MTR. In fact, the finding of the scorecard was influenced very much by political motives [18]. Thus, the delay in the inauguration of the AEC increases the pessimistic outlook on the diminishing chance of the AEC being implemented on schedule.

Since ASEAN announced the establishment of the AEC by building on existing economic schemes such as AFTA, AFAS and AIA and implementing various roadmaps to expedite the AEC, scholars have assessed the success of these economic schemes. In doing so, many weaknesses have been pointed out. However, there are two significant factors: the inherent problems within ASEAN and the increasing role of China in the region. These are two issues that ASEAN is unable to resolve. Significantly, these hurdles remain daunting and continue to shape ASEAN economic integration. 


\subsection{Inherent problems within ASEAN}

The AMS adopted the idea of open regionalism in 1992 under AFTA. Later, economic cooperation was expanded into services and investment sectors under AFAS and AIA. However, the AMS seem less interested in cooperation under these economic schemes. AFTA has been criticized as a 'talk shop' as it has been unable to promote more concrete economic liberalization. Consequently, protectionism continues to prevail among member states in the form of NTBs. "NTBs at the border and behind-the-border are the most prevalent policy tool" for Indonesia, Malaysia, Vietnam, the Philippines, Singapore and Thailand [19]. In 2012, it was found that the number and scope of NTBs has increased and half of the tariffs lines are subject to NTBs [20].

Even though ASEAN has strengthened commitments to reduce the number of NTBs, progress in removing NTBs has been slow. Under AFTA, NTBs have been widely implemented in the agricultural sector. Rice production has been monopolized in Myanmar, Indonesia and the Philippines. Recently, new trade restrictions on agricultural products have been introduced by the Indonesian government. These include the requirement for original labels as a part of the packaging and the prohibition of the use of sticker labels. Furthermore, the government also restricted the quantity of fresh and processed fruits and vegetables under new legislation implemented in 2011. Moreover, prohibition measures for certain product categories have been employed in Brunei, Vietnam, Thailand, Myanmar and Singapore [21]. In Thailand, used cars, engines and electrical appliances are not allowed to be imported into the Kingdom. In Cambodia, "the most notorious barrier against formal trade is the country's opaque system of business and investor licensing [22]. It is widely acknowledge that NTBs mostly manifest as non-automatic licensing, limitation quotas on import or export and foreign exchange restrictions. "To date, ASEAN has failed to tackle NTBs effectively, with many member countries not providing a comprehensive list of NTBs to the ASEAN Secretariat" [23].

"For the single market and production base, implementation in services is the most problematic, followed by investment" because barriers in these sectors are opaque and difficult to identify [24]. In Vietnam, foreign ownership continues to be limited in certain services such as telecommunication. In Malaysia, "trade in services still remains constrained by professional licensing restrictions and cumbersome work-permit procedures" [25]. In fact, limitations on foreign equity ownership is one of the most conspicuous impediments to trade in services. Under the AEC, ASEAN investors will be allowed up to $70 \%$ of equity, however, restrictions and conditions on foreign investment vary among the AMS. Differences in the limitations on foreign equity manifest in the hotel sector, even though the sector is embarked as a priority integration sector. Thailand has increased the hotel equity ownership limit to $70 \%$, however, it has allowed for the investment of more than 500 million baht in 6star plus hotels. Indonesia will allow ASEAN investors to control $100 \%$ equity only in certain locations and the Malaysian government allows ASEAN investors to control 70\% of equity only in 4 and 5 star hotels [26].

Enforceability is a major barrier to the liberalization of investment, as ASEAN allows its members to delay or opt out of the implementation of measures under the banner of ASEAN-X [27]. Bhaskaran [28] points out that obstacles in investment sectors are from domestic interests seeking continued government protection from regional competitors, historical animosities, territorial disputes and mutual suspicion. He also points out that these obstacles are a result of government application and implementation rather than policies [29]. Consequently, ASEAN-X has "the potential to institutionalize a multi-tier ASEAN characterized by fragmented integration" [30].

Though a 'Strategic Schedule' has been implemented to eliminate NTBs on intra- regional trade, the removal of NTBs by ASEAN members is considered a 'voluntary action' for domestic reasons. On the one hand, economic restrictions have been imposed to protect domestic interests and entrepreneurs in Thailand, Malaysia and the Philippines. On the other hand, impediments are also frequently used as a part of economic nationalism as evidenced in Indonesia. Therefore, eliminating NTBs is a unilateral action. Due to a lack of transparent information on NTBs and diverse national rules and regulations, these problems are some of the major obstacles preventing the harmonization of laws and regulations between AMS. To facilitate trade among AMS, ASEAN Single Window (ASW) [31] was implemented in 2005. However, the progress has been slow due to the reluctance of some members to adopt the single system.

Apart from domestic protection, stagnation and slow progress on economic liberalization has been due to the structure of ASEAN institutions. Though the ASEAN Charter had been expected to give tooth to ASEAN institutions, the Charter still upholds loose institutional structures through the non-binding norms and ASEAN way and in the provision of limited power to the ASEAN Secretariat. As long as the principles of consensus and 
non-interference are embedded in ASEAN institutions, these principles will continue to allow AMS to prioritize their national interests over regional cooperation and prevent the harmonization of laws and regulations. At the same time, the ASEAN Secretariat is still limited in its capabilities by a lack of human and financial resources. Due to the lack of financial resources, the Secretariat will face financial constraints due to the dramatically increased scope of operations after 2015. It does not have the power to command, monitor and sanction member states to force them to comply with their commitments. This weakness of the Secretariat was revealed during the slow process of the identification of NTBs. Without more effective and stronger institutional structures with better enforcement mechanisms, it is impossible for ASEAN to eliminate NTBs and achieve a single market. "In the absence of strong regional institutions and sanction mechanisms for non-compliance and non-cooperation, only peer pressure will encourage AMS to respect community commitment" [32].

\subsection{Changing regional economic environment and the increasing role of China as the leading regional power}

ASEAN is committed to strengthening its central role in driving Asian regional economic integration through the principle of 'ASEAN centrality'. This goal is incorporated into the AEC under the Fourth Pillarintegration into the global economy through the creation of ASEAN Plus One FTAs. Consequently, a number of FTAs have been negotiated including ASEAN+3 [33] and ASEAN+6 [34]. The most significant FTA that ASEAN has signed with China is the ASEAN-China free trade agreement (ACFTA) which came into force in 2010. ACFTA is expected to become the world's largest trading bloc and ASEAN aims to access the growing Chinese market in services and manufacturing. To continue and solidify ASEAN centrality, the initiative of Regional Comprehensive Economic Partnership (RCEP) [35] was announced by ASEAN leaders in 2011. Unfortunately, economic cooperation and particularly the increasing engagement of China in ASEAN would eclipse ASEAN's role and undermine the formation of the AEC.

Since the 1990s, China has approached Southeast Asia gradually through deepening economic ties. More importantly, the perception of China as a threat began to change after the 1997 crisis. In fact, Beijing's position and cooperation in Southeast Asia is driven by strategic thinking that is more likely political than economic. Chinese participation raises concern over whether the increasing role of Beijing will affect regional cooperation and cohesion. Though ASEAN is eager to be the center of the regional economy as a hub and a spoke, China's growing stature may foreshadow and undermine ASEAN's cohesion as China is more likely to promote institutions that underscore its predominance [36]. Evidence from the Greater Mekong Subregion (GMS) [37] and ACFTA supports this claim.

Generally, GMS provides many economic benefits by forging greater economic integration beyond ASEAN and enhances ASEAN's overall economic competitiveness. To increase economic development between mainland ASEAN and China, the 'Bridgehead Strategy' which includes massive investment, transportation routes and trade bases, is employed. It is obvious that the CLMV countries see their economic future tied to China far more than to ASEAN, as China is the leading player in integration programs as it channels aid into three economic corridors- North- South, East- West and Southern economic corridors. In the meantime, China is playing a greater catalytic role in economic interdependence between GMS members and China. In doing so, CAFTA has been utilized to promote renminbi settlement in trade exchanges with GMS partners. Furthermore, the differences in the completion phase of ACFTA divide ASEAN into ASEAN-6 and CLMV groups with China as the core of subregional integration. While the ASEAN Secretariat pursued 'Initiatives for ASEAN Integration', the initiative went from strength in ASEAN as a whole to strength in developing a wide array of interactions and interdependencies in mainland Southeast Asia [38]. Hence, the "lopsided development of ASEAN will weaken the organization and diminish its influence as a unified bloc" [39].

Although ASEAN has pursued an aggressive trade strategy, these FTAs may cause the fragmentation of ASEAN unity and derail the AEC. Furthermore, many FTAs are weak as the agreements do not address regulatory bodies and NTBs such as product standards and mutual recognition. Sally [40] states that the FTAs that ASEAN has concluded hardly promote regional economic integration and in turn they do not facilitate the establishment of the AEC. Recently, ASEAN was faced with new challenges due the 'noodle bowl' effect of overlapping FTAs between ASEAN and six dialogue partners (China, South Korea, New Zealand Australia, India, and Japan) as it "increases the costs of doing business due to the impact of rules of origin (ROOs), which facilitate protectionism and create complex patterns of discrimination and exclusion" [41]. However, while the 
noodle bowl effect could be resolved through the RCEP, the flexibility of the RCEP implies it is less ambitious regarding deeper integration. Also, the RCEP would contribute to limited trade and investment liberalization due to different levels on tariff elimination among parties. Significantly, security concerns about China could be a significant source of division within the RCEP. With the escalation of hostilities in the South China Sea Disputes between China and some ASEAN countries, the conflict will strain regional economic integration between Beijing and ASEAN.

\section{Conclusion: How Far Will the AEC Go?}

The AEC project has been crucial for ASEAN because the AEC will strengthen the position of ASEAN as vital regional economic player in Asia. Commitment to the creation of a single market signals to international investors that ASEAN is still a profitable region for trade and investment. As the December 2015 deadline of the AEC approaches, critics point out that many of specific deadlines under the AEC have been missed. Thus most observers believe that the AEC will not be implemented by 2015 or even 2020. The Economic Research Institute for ASEAN and East Asia [42] underscored that without the major achievement of the elimination of NTBs "there cannot be an AEC even if there is tremendous progress in the rest of the AEC measures".

Instead, the AEC should be seen as a single market in ASEAN style with an informal and flexible time frame, rather than comparing it with the EU. Furthermore, the AEC should not be seen as the ultimate goal of regional integration, rather the AEC should be considered as a work in progress [43]. Thus it is likely that no significant changes will occur in 2015, as almost all of the implementation and processes will continue to be carried out. This is because ASEAN has failed to eliminate restrictive regulations such as the NTBs. It has also been unable to deliver deeper economic integration due to the lack of effective mechanisms and weak institutions. At the same time, the changing regional environment and the increasing engagement of China through economic means could distract ASEAN from its goal of a single market. Instead, the increasing engagement of China in ASEAN will divide ASEAN into two tiers: mainland and maritime.

\section{References}

[1] J. Ruland and A. Jetschke, "40 Years of ASEAN: Perspectives, Performance and Lessons for Chance," The Pacific Review, vol. 21 (1), pp. 398, December 2008.

http://dx.doi.org/10.1080/09512740802294705

[2] AFTA was signed in 1992 and came into force in 1993. Under AFTA, ASEAN members signed an agreement on the Common Effective Preferential Tariff (CEPT) Scheme in 1992. The CEPT aims to eliminate tariffs and non-tariff barriers in the region. In 2010, CEPT-AFTA was replaced by ASEAN Trade in Goods Agreement (ATIGA).

[3] AFAS was agreed at the $5^{\text {th }}$ ASEAN Summit in 1995. The Agreement requires ASEAN to progressively enhance market access and guarantee equal national treatment on services. Furthermore, the AFAS attempts to be GATS-Plus.

[4] AIA was signed in 1998. It aimed at providing an environment that will facilitate free flows of investment, technology and skills and inclusion in regional and global production networks. In 2009, ASEAN adopted the ASEAN Comprehensive Investment Agreement (ACIA) which is an enhanced vision of the AIA.

[5] K. Freistein, "ASEAN after the Bali Summit: From Paralysis to New Life," European Journal of East Asian Studies, vol. 4(2), pp. 177-204, 2005. http://dx.doi.org/10.1163/157006105774711440

[6] The ASEAN Economic Community (AEC) is one of the three pillars of ASEAN Community. The other two pillars are the ASEAN Security Community and ASEAN Socio-cultural Community. These pillars are closely intertwined and mutually reinforcing for the purpose of ensuring durable peace, stability and shared prosperity in the region.

[7] The deadline to realize the AEC was brought forward to 2015 at the ASEAN summit held in Cebu in 2007.

[8] Generally, NTBs refer to any measure, other than tariffs that distorts trade. Distortions include border and behind-theborder measures that arise from government regulatory policies, procedures and administrative requirements that are imposed to serve a particular purpose (Austria 2013). NTBs include those such as quotas, health and environmental regulations, licensing requirements, and mandatory product inspections.

[9] R. Severino and J. Menon, "Overview," in The ASEAN Community: A Work In Progress, Singapore: ISEAS Publishing, 2013, ch 1, pp. 1-30. 
[10] K. Freistein, "ASEAN after the Bali Summit: From Paralysis to New Life," European Journal of East Asian Studies, vol. 4(2), pp. 177-204, 2005.

http://dx.doi.org/10.1163/157006105774711440

[11] J. Ravenhill, "Fighting irrelevance: an economic community 'with ASEAN characteristics," The Pacific Review no. 21 (4), pp. 469-488, December 2008.

[12] The ASEAN Economic Community (AEC) is one of the three pillars of ASEAN Community. The other two pillars are the ASEAN Security Community and ASEAN Socio-cultural Community. These pillars are closely intertwined and mutually reinforcing for the purpose of ensuring durable peace, stability and shared prosperity in the region.

[13] R. Severino and J. Menon, “Overview," in The ASEAN Community: A Work In Progress, Singapore: ISEAS Publishing, 2013, ch 1, pp. 4.

[14] W. Jones, "The ASEAN Economic Community and new regionalism: a neorealist analysis," ASIEN- The German Journal on Contemporary Asia, vol. 119, pp. 49-66, April 2011.

[15] S. Y. Chia. (October 2013). The ASEAN Economic Community: Progress, Challenges and Prospects. ADBI Working Paper Series. 440. pp. 1-37. [Online]. Available: http://www.adb.org/sites/default/files/publication/156295/adbiwp440.pdf.

[16] Economic Research Institute for ASEAN and East Asia (ERIA). Mid-Term Review of the Implementation of AEC Blueprint. [Online]. 2012. Available: http://www.eria.org/MidTerm\%20Review\%20of\%20the\%20Implementation\%20of\%20AEC\%20Blue\%20Print-Executive\%20Summary.pdf.

[17] J. Xianbail. (September 2014). Why the ASEAN Economic Community will struggle. The Diplomat. [Online]. Available: http://thediplomat.com/2014/09/why-the-asean-economic-community-will-struggle/

[18] Economic Research Institute for ASEAN and East Asia (ERIA). Mid-Term Review of the Implementation of AEC Blueprint. [Online]. 2012. Available: http://www.eria.org/MidTerm\%20Review\%20of\%20the\%20Implementation\%20of\%20AEC\%20Blue\%20Print-Executive\%20Summary.pdf.

[19] M. Austria. "Non-tariff barriers: a challenge of achieving the ASEAN Economic Community," in The ASEAN Economic Community: a work in progress, S. B. Das, J. Menon, R. Severino, O. L. Shrestha, Eds.Singapore : ISEAS Publishing, 2013. Ch. 2, pp. 42.

[20] Nontariff Barriers to Trade: RATE Summary. USAID Regional Development Mission for Asia, [Online], 2013. Available: https://www.usaid.gov/sites/default/files/documents/1861/Nontariff_barriers.pdf.

[21] S. Areethamsirikul, "The impact of ASEAN enlargement on economic integration: successes and impediments under ASEAN political institution", PhD thesis, Development Studies, University of Wisconsin-Madison, Wisconsin, the United States, 2008.

[22] Nontariff Barriers to Trade: RATE Summary. USAID Regional Development Mission for Asia, [Online], 2013. Available: https://www.usaid.gov/sites/default/files/documents/1861/Nontariff_barriers.pdf.

[23] D. Hew, "Towards an ASEAN Economic Community by 2015," in The ASEAN Community: Unblocking the Roadblocks, ASEAN Studies (Report No. 1), Singapore: Institute of Southeast Asian Studies, 2008, ch 1, pp. 22.

[24] S. Y. Chia. (October 2013). The ASEAN Economic Community: Progress, Challenges and Prospects. ADBI Working Paper Series. 440. pp. 28. [Online]. Available: http://www.adb.org/sites/default/files/publication/156295/adbiwp440.pdf.

[25] Nontariff Barriers to Trade: RATE Summary. USAID Regional Development Mission for Asia, [Online], 2013. Available: https://www.usaid.gov/sites/default/files/documents/1861/Nontariff_barriers.pdf.

[26] 31 December 2015: Deadline for AEC launch and obstacles that still remain. Economic Intelligence Center. January 2015. [Online]. Available: https://119-46-87-73.static.asianet.co.th/en/detail/product/1150.

[27] R. Severino and J. Menon, “Overview," in The ASEAN Community: A Work In Progress, Singapore: ISEAS Publishing, 2013, ch 1, pp. 1-30.

[28] M. Bhaskarn. "The ASEAN Economic Community: the investment climate," in The ASEAN Economic Community: a work in progress, S. B. Das, J. Menon, R. Severino, O. L. Shrestha, Eds.Singapore : ISEAS Publishing, 2013. Ch. 4, pp. 141-206.

[29] M. Bhaskarn. "The ASEAN Economic Community: the investment climate," in The ASEAN Economic Community: a work in progress, S. B. Das, J. Menon, R. Severino, O. L. Shrestha, Eds.Singapore : ISEAS Publishing, 2013. Ch. 4, pp. 141-206.

[30] J. Ravenhill, "Fighting irrelevance: an economic community 'with ASEAN characteristics," The Pacific Review no. 21 (4), pp. 481, December 2008. 
[31] ASEAN Single Window (ASW) is ASEAN initiative to connect and integrate National Single Windows of member states. ASW will expedite customs procedures within ASEAN by setting-up a single clearance channel for goods for ASEAN-6 by 2008 and CLMV countries by 2012.

[32] J. Xianbail. (September 2014). Why the ASEAN Economic Community will struggle. The Diplomat. [Online]. Available: http://thediplomat.com/2014/09/why-the-asean-economic-community-will-struggle/

[33] ASEAN+3 comprises the ten ASEAN members plus China, Japan and South Korea.

[34] ASEAN+6 or East Asia Summit Group comprises ASEAN+3, Australia, New Zealand, and India.

[35] The Regional Comprehensive Economic Partnership (RCEP) was introduced by ASEAN in 2011. The RCEP includes the ASEAN states, China, Japan, South Korea, Australia, New Zealand, and India.

[36] J. Wright. (November 2013). Rising Regionalism: Trends in Southeast (and Wider) Asia. Council on Foreign Relations. [Online]. Available: file://C:/Users/TOSHIBA/Downloads/Rising_Regionalism_Meeting_Note_11-15$13 \% 20(1) \cdot p d f$.

[37] The Greater Mekong Subregion comprises Cambodia, Laos, Myanmar and Vietnam as well as Thailand and two Chinese provinces, Yunnan and Guangxi.

[38] G. Wade. (February 2011). Could ASEAN drift apart?. YaleGlobal Online. [Online]. Available: http://yaleglobal.yale.edu/content/could-asean-drift-apart.

[39] G. Wade. (February 2011). Could ASEAN drift apart?. YaleGlobal Online. [Online]. Available: http://yaleglobal.yale.edu/content/could-asean-drift-apart.

[40] R. Sally. "ASEAN FTAs: state of play and outlook for ASEAN's regional and global integration," in The ASEAN Economic Community: a work in progress, S. B. Das, J. Menon, R. Severino, O. L. Shrestha, Eds.Singapore : ISEAS Publishing, 2013. Ch. 7, pp. 320-381.

[41] A. Capling and J. Ravenhill, "Multilateralising regionalism: what role for the Trans-Pacific Partnership Agreement?," The Pacific Review no. 24(5), pp. 556. December 2011.

[42] Economic Research Institute for ASEAN and East Asia (ERIA). Mid-Term Review of the Implementation of AEC Blueprint. [Online]. 2012. Available: http://www.eria.org/MidTerm\%20Review\%20of\%20the\%20Implementation\%20of\%20AEC\%20Blue\%20Print-Executive\%20Summary.pdf.

[43] S. Das. (May 2015). The ASEAN Economic Community: A Work in Progress. The Diplomat. [Online]. Available: http://thediplomat.com/2015/05/the-asean-economic-community-a-work-in-progress/ 